\title{
Effects of Prenatal Education and Type Of Delivery On Stress Axes
}

\author{
Stres Aksı Ůzerine Doğum Tipi ve Prenatal Eğitimin Etkileri \\ Cihat UÇAR ${ }^{1} \mathbb{D}$, Mehmet BÜLBÜL ${ }^{2} \mathbb{D}$, Sedat YILDIZ ${ }^{3}$ \\ ${ }^{1}$ Department of Physiology, Faculty of Medicine, University of Adıyaman, Turkey \\ 2 Department of Gynecology and Obstetrics, Faculty of Medicine, University of Karabük, 78000 Karabük, Turkey \\ ${ }^{3}$ Department of Physiology, Faculty of Medicine, University of Inonu, Malatya, Turkey
}

Background: Training received during pregnancy may alter the prenatal stress level. The purpose of this study was to investigate the effects of prenatal education on the stress axis of the body, namely the hypothalamo- pituitary adrenal axis (HPA) and autonomic nervous system (ANS) in different delivery types (vaginal or caesarean section).

Materials and Methods: In this prospective study, women who were going to have caesarean or vaginal delivery were compared in terms of whether they undertook prenatal education (PNE) in pregnancy school or not. Among those of women having PNE, twenty women had caesarean delivery and, therefore, the number of women in other groups was decided accordingly. As a result, a total of 4 groups were formed as follows: women having PNE/caesarean delivery $(n=20)$, having PNE/vaginal delivery $(n=20)$, not having PNE/having caesarean delivery $(n=20)$ and not having PNE/having vaginal delivery $(n=20)$. In these women, the prenatal HPA and ANS activities were measured non-invasively with saliva cortisol and heart rate variability (HRV), respectively. HRV was measured by 5-min electrocardiogram recording and time- and frequency-domains parameters were calculated.

Results: The (PNE) did not affect the prenatal cortisol and HRV parameters in none of the delivery types (vaginal and caesarean) ( $p>0.05)$. HRV parameters were higher in women having vaginal delivery than those of caesarean delivery $(P<0.05)$. No correlations were observed between the cortisol and HRV parameters $(P>0.05)$.

Conclusion: The prenatal education had no effect on HPA and ANS; however, the delivery type altered the HRV parameters. Saliva cortisol and HRV may be useful parameters in terms of examining the physiology of the birth process

Key Words: Cortisol, Heart rate variability, Prenatal education, Vaginal delivery, Caesarean delivery

öz.

Amaç: Gebelik döneminde alınan eğitim doğum öncesi stres seviyesini değiştirebilir. Bu çalışmanın amacı, prenatal eğitimin farklı doğum tiplerinde (vajinal veya sezaryen), vücudun stres aksı üzerine yani hipotalomo-hipofiz adrenal aks (HPA) ve otonom sinir sistemi (ANS) üzerindeki etkilerini araştırmaktı.

Materyal ve Metod: Bu prospektif çalışmada sezaryen veya vajinal doğum yapacak kadınlar gebelik okulunda doğum öncesi eğitim (PNE) alıp almamaları açısından karşılaştırıldı. PNE'si olan kadınlardan yirmisi sezaryen ile doğum yapmış ve bu nedenle diğer gruplardaki kadın sayısı buna göre kararlaştırılmıştır. Sonuç olarak toplam 4 grup şu şekilde oluştu: PNE/sezaryen doğum yapanlar ( $n=20)$, PNE/vajinal doğum yapanlar $(n=20)$, prenatal eğitim almayan/sezaryen doğum yapanlar $(n=20)$ ve prenatal eğitim almayan/vajinal doğum yapanlar $(n=20)$. Bu kadınlarda doğum öncesi HPA ve ANS aktiviteleri, sırasıyla tükürük kortizolü ve kalp hızı değişkenliği (HRV) ile non invazif ölçüldü. HRV, 5 dakikalık elektrokardiyogram kaydı ile ölçüldü ve zaman-bağımlı ve frekans bağımlı parametreler hesaplandı.

Bulgular: Prenatal eğitim (PNE) her iki doğum tipinde (vajinal ve sezaryen) doğum öncesi kortizol ve HRV parametrelerini etkilememiştir ( $p>0.05)$. HRV parametreleri vajinal doğum yapanlarda sezaryen doğum yapanlardan daha yüksekti $(p<0.05)$. Kortizol ve HRV parametreleri arasında herhangi bir korelasyon gözlenmedi ( $p>0.05)$.

Sonuç: Prenatal eğitimin HPA ve ANS etkisi olmamıştır fakat doğum tipi HRV parametrelerini değiştirmiştir. Tükürük kortizolü ve HRV, doğum sürecinin fizyolojisini incelemek açısından yararlı parametreler olabilir.

Anahtar kelimeler: Kortizol, Kalp hızı değişkenliği, Prenatal eğitim, Vajinal doğum, Sezaryen doğum

\section{Corresponding Author / Sorumlu Yazar}

\section{Dr. Cihat UÇAR}

Adıyaman University

Faculty of Medicine

Department of Physiology

Adiyaman, Turkey

e-Mail: ucarcht@gmail.com

Received / Geliş tarihi: 07.10 .2021

Accepted / Kabul tarihi: 14.12.2021

DOI: 10.35440/hutfd.1005965 


\section{Introduction}

Pregnancy is a period in which physiological, psychological and social changes occur in woman's life (1). The woman needs to adapt to the changes occurring in this period. Despite the adaptation, pregnancy is a stressful period for women. Especially for mothers who have their first pregnancy, the pregnancy process and birth are terrifying and worrisome events (1). Therefore, the support and education to be provided to pregnant women are crucial. To pregnant women at the pregnant school; training was provided to enable them to have knowledge and skills on pregnancy, pregnancy exercise and yoga, labor, baby care, breastfeeding, newborn health, puerperium, postpartum exercises and yoga, and family planning. The education to be provided to pregnant women during the prenatal period has several positive effects. It is reported that the education has a positive effect on the relationship between couples, increases the health consciousness in pregnant women and provides information especially about the pregnancy process and birth. For that purpose, informing classes are opened for pregnant women in Turkey and in the world. With the education provided in these classes for pregnant women, it is aimed to enable expectant mothers to have information about subjects related to pregnancy and birth. However, it is not known how being informed of birth affects the stress response in pregnant women.

There are two main systems creating the stress response in humans. The first of these is the hypothalamo- pituitary adrenal axis (HPA) and the second one is the autonomic nervous system (ANS). Cortisol is released from the suprarenal gland as an end product of the HPA axis (3). Approximately $96 \%$ of cortisol is bound to the proteins in blood (4). Cortisol which is bound to the proteins is present in an inactive form. Free cortisol is its active form and it mixes with all bodily fluids (5). Especially cortisol which is available in saliva is commonly used in stress studies because it facilitates non-invasive measurement and is in an active form (5). For this reason, the saliva cortisol measurement is used in psychoneuroendocrinological studies (6). The other system activated by stress is the ANS. Its two divisions, i.e. sympathetic and parasympathetic nervous branches, accelerate or slow down the heart rate, respectively. Thus, in a healthy human, heart rate fluctuates over time due to competing activities of these two branches (7). Heart rate variability (HRV) is accepted as a non-invasive surrogate technic for determination of sympatho-vagal balance on the heart rate.

The purpose of the present study was to examine the effects of receiving education on cortisol and HRV in the pregnancy school.

\section{Materials and Methods}

The study started after obtaining approval from Adıyaman University Non-invasive Clinical Trials Ethics Committee (Date:20/03/2019 Decision number: 2019/2-26). 80 pregnant women (prenatal education $=40$, non-prenatal education as control group=40) who had no known disease, were older than 18 years were included in the study. Those taking anxiolytics and antidepressants, receiving psychological support in any phase of pregnancy and having a high-risk pregnancy (such as hypertension, diabetes, fetal anomaly) were not included in the study. In this prospective study, women who were going to have caesarean or vaginal delivery were compared in terms of whether they undertook prenatal education (PNE) in pregnancy school or not. Among those of women having PNE, twenty women had caesarean delivery and, therefore, the number of women in other groups was decided accordingly. As a result, a total of 4 groups were formed as follows: women having $\mathrm{PNE} /$ caesarean delivery $(n=20)$, having $P N E /$ vaginal delivery $(n=20)$, not having $P N E /$ having caesarean delivery $(n=20)$ and not having $P N E /$ having vaginal delivery $(n=20)$. In those who would have a vaginal delivery, a saliva sample was received to determine the HPA activity when the cervical openness was less than $2 \mathrm{~cm}$ and a 5-minute ECG record was received to determine the Autonomic Nervous System (ANS) activity. In those who would have a caesarean section, a saliva sample and ECG record were received when they were hospitalized in the service (before the application of anesthesia).(Figure 1)

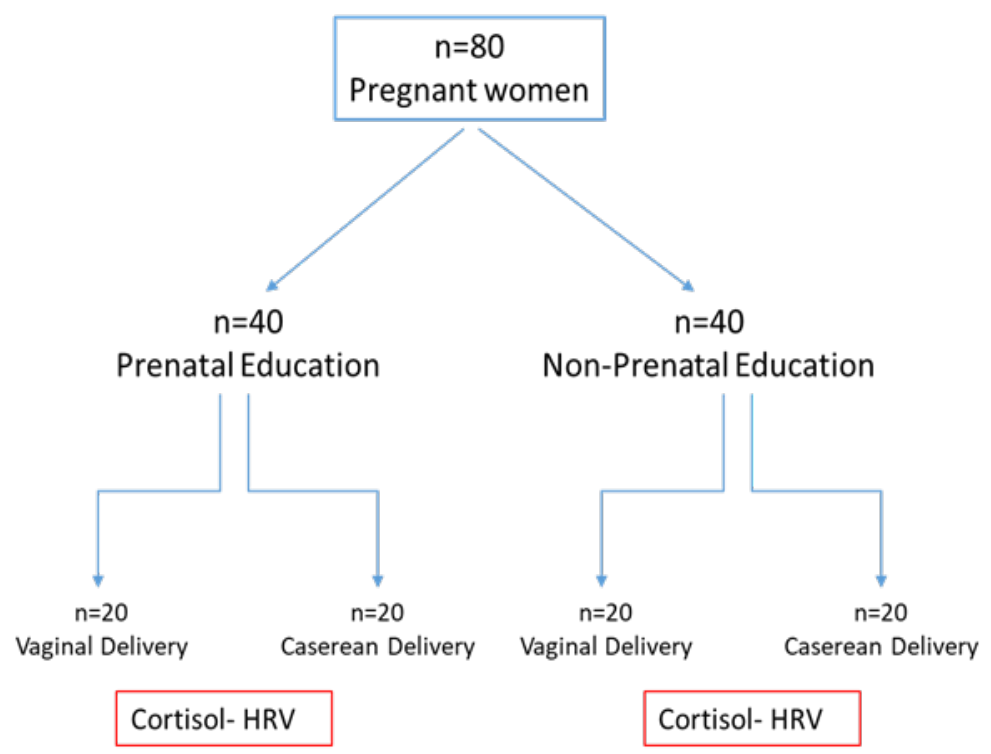

Figure 1. Study Design

In order to collect saliva, $1.5 \mathrm{ml}$ polypropylene tubes (Isolab) were used. Tags were put on the tubes and two samples were received from each participant before and after birth. The saliva collection process was conducted using the passive droll method (8). The participants did not consume any food-beverage and did not brush their teeth until 30 minutes before the saliva sample collection. The saliva samples collected were kept until being analyzed at $-45^{\circ} \mathrm{C}$. Salivary cortisol analyses were carried ac- 
cording to Ozgocer et al. $(9,10)$. Briefly, 96-well microplates (Nunc, Denmark) were coated with cortisol-BSA (bovine serum albumin) overnight at $4{ }^{\circ} \mathrm{C}$ and blocked with $200 \mu \mathrm{l} \mathrm{BSA} \mathrm{(1 \% )} \mathrm{for} 2 \mathrm{~h}$ at $37^{\circ} \mathrm{C}$. The samples were thawed and centrifuged at $4000 \mathrm{~g}$ for $10 \mathrm{~min}$ before adding into the microplates. The supernatant obtained was diluted 3 times in assay buffer before using in the assay. Salivary samples and standards $(0,1,5,10,20,40,100$, $1000 \mathrm{ng} / \mathrm{ml}$ ) were added in duplicate $(40 \mu \mathrm{l})$ to the wells together with $40 \mu \mathrm{l}$ diluted rabbit anti-cortisol antibodies. Plates were incubated $45 \mathrm{~min}$ at $37^{\circ} \mathrm{C}$, and were washed 5 times with wash buffer and $100 \mu$ l biotinylated goat-anti rabbit antibody was added. This was followed by incubation at $37^{\circ} \mathrm{Cfor} 30 \mathrm{~min}$. Plates were then washed 5 times with wash buffer. Streptavidin peroxidase $(100 \mu \mathrm{l})$ was added and the plates were incubated for $15 \mathrm{~min}$ at $4{ }^{\circ} \mathrm{C}$. Following washing 5 times with wash buffer, $150 \mu \mathrm{l}$ substrate solution (tetramethyl benzidine) was added. Blue color formed was stopped by $50 \mu \mathrm{l}$ sulphuric acid and plates were read by a plate-reader spectrophotometer (Biotek, Synergy HT, USA). Calibration curves were produced by using 4-parameters logistic regression curves (Gen5, Biotek, USA) and cortisol levels were quantified by using this curve. Minimum detection limit was $1 \mathrm{ng} / \mathrm{ml}$ and intra- and inter-assay coefficients of variations were 11.6 and $13.8 \%$, respectively. For HRV measurement a 5-min continuous ECG was recorded. ECG was recorded in supine positions with eyes open. Poly-Spectrum 8-E (Russia) was used for ECG record and a software program (Neurosoft, Ivanovo, Russia) provided with the same device was used to analyze heart rate variability (HRV) parameters. Time- and frequency-domain parameters of the HRV are calculated by the software. The most used time-domain variables are SDNN (standard deviation of normal-to-normal intervals), RMSSD (root mean square of successive differences) and pNN50 (normal-to-normal $\mathrm{R}-\mathrm{R}$ intervals that differ by more than $50 \mathrm{~ms}$ ) parameters. The most used frequency-domain variables are TP (total power), LF (low frequency), HF (high frequency), LF n.u (low frequency normalized units), HF n.u (high frequency normalized units) and LF/HF ratio. All of these parameters were included in the study. For the all statistical analyses, the Minitab program was used. For the statistical analysis, the General Linear Models 2x2 factorial design was employed. For the non-normally distributed data, the BoxCox Transformation was applied (optimal $\lambda$ transformation was conducted). The data were presented as mean \pm standard deviation (SD). A $p$ value of $\leq 0.05$ was considered to be statistically significant.

\section{Results}

Education in pregnancy school and delivery type did not affect pre-delivery cortisol concentration ( $p>0.05$, Figure 2). No interactions were observed in terms of cortisol levels $(P>0.05)$.

HRV parameters were not affected by prenatal education $(p>0.05)$ but they were affected by type of delivery $(p<0.05)$. Type of delivery affected both time-domain (RMSSD, and pNN50) and frequency-domain parameters (LF, HF, and \% HF; $p<0.05$, Table 1). These parameters were higher in those of women who had vaginal delivery than those of women who had caesarean delivery $(p<0.05)$. LF n. $u$ was higher in those of women who had caesarean delivery than those of women who had vaginal delivery $(p<0.05)$. No interactions were observed for time- and frequency-domain variables of HRV ( $p>0.05)$.

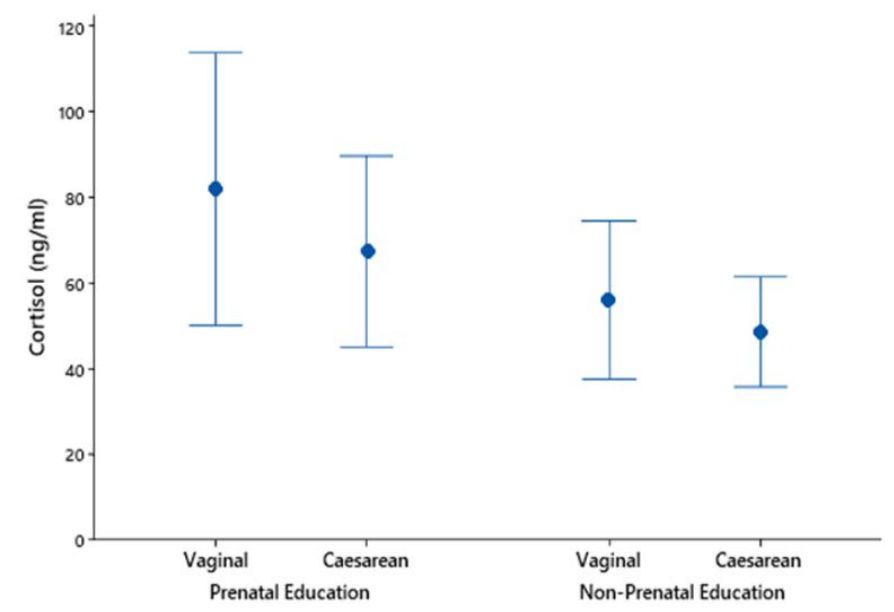

Figure 2. Cortisol levels in vaginal and caesarean delivery of prenatal education and non-prenatal education (mean \pm SD). Education in pregnancy school and delivery type did not affect pre-delivery cortisol concentration $(p>0.05)$.

\section{Discussion}

The pregnancy process and especially birth are accepted to be stressful situations. Receiving education on changes that occur throughout pregnancy contributes to going through this process more easily. Human body needs to activate the stress axes in order to cope with such stressful situations. The present study investigated the effect of education received during pregnancy (PNE) on the two main stress axes (HPA and ANS). The prenatal education did not affect the HPA and ANS system before birth; however, the delivery type affected the ANS rather than the HPA.

Although the prenatal education provided information about the pregnancy process, it did not affect the cortisol level before birth. Under normal circumstances cortisol is a hormone released as a reaction to stressful conditions and therefore the increase of its secretion is used as a stress indicator (11). In addition, this hormone has vital effects in terms of coping with the effects of stress (12). Increase of the cortisol secretion at the end of pregnancy may be necessary to start birth. Higher cortisol prepares both the mother and the infant to birth (13). In the present study, the prenatal education had no effect on the cortisol level. This is because increase of the cortisol before birth facilitates birth. 
Table 1. HRV parameters in vaginal and cesarean delivery of prenatal education and non-prenatal education (mean \pm SD).

\begin{tabular}{|c|c|c|c|c|c|c|c|}
\hline & \multicolumn{2}{|c|}{$\begin{array}{l}\text { GROUPS } \\
\text { Prenatal Education }\end{array}$} & \multicolumn{2}{|c|}{ Non-Prenatal Education } & \multirow{2}{*}{$\begin{array}{l}\text { P Values } \\
\text { Education } \\
\text { Status }\end{array}$} & \multirow[b]{2}{*}{$\begin{array}{l}\text { Delivery } \\
\text { Type }\end{array}$} & \multirow[b]{2}{*}{ Interaction } \\
\hline & Vaginal & Caesarean & Vaginal & Caesarean & & & \\
\hline HR (bpm) & $90.09 \pm 16.9$ & $95.1 \pm 11.4$ & $90.4 \pm 16.6$ & $97.1 \pm 14.5$ & 0.954 & 0.175 & 0.899 \\
\hline RRNN (ms) & $686 \pm 125$ & $638 \pm 74$ & $684 \pm 125$ & $630 \pm 89$ & 0.943 & 0.174 & 0.898 \\
\hline SDNN (ms) & $48.6 \pm 28.9$ & $34.8 \pm 8.4$ & $54.1 \pm 23.01$ & $35.7 \pm 13.9$ & 0.371 & 0.037 & 0.463 \\
\hline RMSSD (ms) & $37.7 \pm 27.4$ & $14.1 \pm 7.02$ & $41.9 \pm 30.7$ & $20.6 \pm 10.9$ & 0.874 & 0.015 & 0.668 \\
\hline pNN50 (\%) & $19.2 \pm 22.4$ & $1.14 \pm 2.09$ & $\begin{array}{l}13.19 \\
\pm 16.3\end{array}$ & $3.1 \pm 3.5$ & 0.327 & 0.003 & 0.377 \\
\hline $\mathrm{TP}\left(\mathrm{ms}^{2}\right)$ & $3014 \pm 2014$ & $1263 \pm 514$ & $3004 \pm 2364$ & $1412 \pm 1373$ & 0.406 & 0.036 & 0.474 \\
\hline $\operatorname{VLF}\left(m s^{2}\right)$ & $1572 \pm 2599$ & $892 \pm 489$ & $1479 \pm 903$ & $950 \pm 1150$ & 0.351 & 0.113 & 0.413 \\
\hline $\mathrm{LF}\left(\mathrm{ms}^{2}\right)$ & $627 \pm 625$ & $276 \pm 196$ & $915 \pm 849$ & $311 \pm 215$ & 0.415 & 0.049 & 0.546 \\
\hline $\mathrm{HF}\left(m s^{2}\right)$ & $815 \pm 1013$ & $95 \pm 101$ & $609 \pm 708$ & $150 \pm 130$ & 0.787 & 0.029 & 0.691 \\
\hline LF n.u & $59.8 \pm 21.8$ & $79.3 \pm 11.85$ & $67.8 \pm 19.1$ & $71.6 \pm 16.3$ & 0.187 & 0.044 & 0.167 \\
\hline HF n.u & $40.1 \pm 21.8$ & $20.7 \pm 11.85$ & $32.2 \pm 19.1$ & $28.4 \pm 16.3$ & 0.217 & 0.066 & 0.197 \\
\hline LF/HF & $2.45 \pm 2.22$ & $6.4 \pm 5.9$ & $4.8 \pm 5.6$ & $6.3 \pm 9.5$ & 0.207 & 0.066 & 0.204 \\
\hline$\%$ VLF & $54.4 \pm 19.9$ & $65.5 \pm 24.4$ & $56.7 \pm 18.9$ & $61.5 \pm 19.7$ & 0.703 & 0.276 & 0.682 \\
\hline$\%$ LF & $24.5 \pm 10.9$ & $27.5 \pm 21.5$ & $28.4 \pm 12.7$ & $27.2 \pm 16.2$ & 0.725 & 0.888 & 0.834 \\
\hline$\% \mathrm{HF}$ & $21.1 \pm 17.1$ & $7.22 \pm 5.89$ & $14.9 \pm 10.5$ & $11.2 \pm 6.88$ & 0.213 & 0.033 & 0.188 \\
\hline
\end{tabular}

SDNN (standard deviation of normal-to-normal intervals), RMSSD (root mean square of successive differences), pNN50 (normal-to-normal R-R intervals that differ by more than $50 \mathrm{~ms}$ ), TP (total power), LF (low frequency), HF (high frequency), LF n.u (low frequency normalized units), HF n.u (high frequency normalized units) and LF/HF ratio.

Also in the present study the different type of delivery did not affect the prenatal cortisol concentration. Examining the literature we have encountered no study on the effects of prenatal education provided during pregnancy on the prenatal cortisol concentration. However, there are studies on the effects of delivery type on the prenatal cortisol concentration. In the studies, the cortisol concentration was found to be higher in those having a vaginal delivery compared to those having a caesarean section (14; 15). Examining these studies it is seen that there are differences with the present study in terms of materialsmethods. The cortisol measurement was performed by drawing blood. Cortisol in blood is bound to globulin. In other words it is an inactive mode of cortisol (4). The procedure of drawing blood itself creates stress (white coat stress). In the present study, the saliva cortisol measurement was performed. Cortisol in saliva is not bound to globulin. In other words it is an active mode of cortisol in free form. Collection of saliva does not create white coat stress in the patient. Therefore the fact that the cortisol concentration was not affected by the type of delivery in the present study might be associated with the aforementioned reasons.

In the present study, the prenatal education had no effect on the time-and-frequency-domain HRV parameters. However, the type of delivery altered the HRV parameters. The HRV parameters were lower in the women having a caesarean section; however, it is difficult to reveal the pathophysiological reasons and consequences of these changes. In the literature review we found no other study evaluating the effects of the birth process on HRV in women. When evaluating the data acquired from the present study, it is thought that the peripartum evaluation of HRV is physiologically important, because the HRV parameters dynamically change in the birth process. Likewise, explaining the reasons and consequences of these changes will provide important information to neurological evaluation of the birth process. As lower HRV is associated with bad health consequences, caesarean section is not recommended because HRV is low in women having a caesarean section. Uterus contractions during birth start the cardiovascular reflex $(16 ; 17)$. Increase of uterus 
contractions in those having a vaginal delivery might have increased the HRV parameters. These changes in HRV might have been caused by the anesthesia applied in caesarean section. However, the samples in the present study were collected prior to the anesthesia. Therefore it is a lower possibility that the changes were associated with anesthesia use.

In the present study, the prenatal education had no effect on HPA and ANS; however, the delivery type altered the HRV parameters. Saliva cortisol and HRV may be useful parameters for examining the physiology of the birth process.

Ethical Approval: Ethical approval for this study was obtained from Adiyaman University Clinical Research Ethical Committee (Date 20/03/2019 Decision number: 2019/2-26).

\section{Author Contributions:}

Concept: C.U., M.B., S.Y.

Literature Review: C.U.

Design : C.U., M.B., S.Y.

Data acquisition: C.U., M.B., S.Y.

Analysis and interpretation: C.U., M.B., S.Y.

Writing manuscript: C.U., M.B., S.Y.

Critical revision of manuscript: M.B., S.Y.

Conflict of Interest: The authors have no conflicts of interest to declare.

Financial Disclosure: Authors declared no financial support.

\section{References}

1. Dunkel Schetter $C$, Tanner L. Anxiety, depression and stress in pregnancy: implications for mothers, children, research, and practice. Curr Opin Psychiatry. 2012;25(2):141-8.

2. Cherak SJ, Giesbrecht GF, Metcalfe A, Ronksley PE, Malebranche ME. The effect of gestational period on the association between maternal prenatal salivary cortisol and birth weight: A systematic review and meta-analysis. Psychoneuroendocrinology. 2018;94:49-62.

3. Tsigos C, Kyrou I, Kassi E, Chrousos GP. Stress: Endocrine Physiology and Pathophysiology. 2020 Oct 17. In: Feingold KR, Anawalt B, Boyce A, Chrousos G, de Herder WW, Dhatariya K, et al. Endotext [Internet]. South Dartmouth (MA): MDText.com, Inc.; 2000.

4. Levine A, Zagoory-Sharon O, Feldman R, Lewis JG, Weller A. Measuring cortisol in human psychobiological studies. Physiol Behav. 2007 Jan 30;90(1):43-53.

5. Kaushik A, Vasudev A, Arya SK, Pasha SK, Bhansali S. Recent advances in cortisol sensing technologies for point-of-care application. Biosens Bioelectron. 2014 Mar 15;53:499-512.

6. Hellhammer DH, Wüst $S$, Kudielka BM. Salivary cortisol as a biomarker in stress research. Psychoneuroendocrinology. 2009;34(2):163-171.

7. Shaffer F, McCraty R, Zerr CL. A healthy heart is not a metronome: an integrative review of the heart's anatomy and heart rate variability. Front Psychol. 2014 Sep 30;5:1040.

8. Uçar C, Özgöçer T, Yıldız S. Effects of late-night eating of easily-or slowly-digestible meals on sleep, hypothalamo-pituitaryadrenal axis, and autonomic nervous system in healthy young males. Stress Health. 2021;37(4):640-649.

9. Ozgocer T, Yildiz S, Uçar C. Development and validation of an enzyme-linked immunosorbent assay for detection of cortisol in human saliva. J Immunoassay Immunochem. 2017;38(2):147164.

10. Ozgocer T, Ucar C, Yildiz S. Cortisol awakening response is blunted and pain perception is increased during menses in cyclic women. Psychoneuroendocrinology. 2017;77:158-164.

11. Zhang $H$, Yao Z, Lin L, Sun $X$, Shi $X$, Zhang L. Early life stress predicts cortisol response to psychosocial stress in healthy young adults. Psych J. 2019;8(3):353-362.

12. Fogelman N, Canli T. Early life stress and cortisol: A metaanalysis. Horm Behav. 2018;98:63-76.

13. Benfield RD, Newton ER, Tanner CJ, Heitkemper MM. Cortisol as a biomarker of stress in term human labor: physiological and methodological issues. Biol Res Nurs. 2014;16(1):64-71.

14. Stjernholm YV, Nyberg A, Cardell M, Höybye C. Circulating maternal cortisol levels during vaginal delivery and elective cesarean section. Arch Gynecol Obstet. 2016;294(2):267-71.

15. Kiriakopoulos N, Grigoriadis S, Maziotis E, Philippou A, Rapani A, Giannelou $P$, et al. Investigating Stress Response during Vaginal Delivery and Elective Cesarean Section through Assessment of Levels of Cortisol, Interleukin 6 (IL-6), Growth Hormone (GH) and Insulin-Like Growth Factor 1 (IGF-1). J Clin Med. 2019 Jul 27;8(8):1112.

16. Sanghavi M, Rutherford JD. Cardiovascular physiology of pregnancy. Circulation. 2014 Sep 16;130(12):1003-8.

17. Soma-Pillay P, Nelson-Piercy C, Tolppanen H, Mebazaa A. Physiological changes in pregnancy. Cardiovasc J Afr. 2016 MarApr;27(2):89-94. 